\title{
ANALISIS PENGARUH JUMLAH UANG BEREDAR, SUKU BUNGA SBI DAN NILAI TUKAR TERHADAP INFLASI DI INDONESIA
}

\begin{abstract}
A. Mahendra
Abstrak

Inflasi adalah salah satu efek dari krisis ekonomi yang berkepanjangan yang dapat melanda suatu negara. Inflasi adalah suatu keadaan dimana terdapat kenaikan harga tajam yang terus menerus selama periode waktu. Tujuan dari penelitian ini adalah menganalisis kebijakan moneter yang dilakukan oleh Bank Indonesia dengan variabel jumlah uang beredar, suku bunga dan nilai tukar SBI (IDR / USD) terhadap inflasi. Metode yang digunakan adalah regresi linear dimana hasil tes menunjukkan efek variabel pada jumlah uang beredar, tingkat suku bunga SBI, dan nilai tukar (Rp / USD) pada tahun 2005 sampai 2014. Dengan menggunakan software spss 22 diperoleh hasil penelitian bahwa jumlah uang beredar dan nilai tukar (Rp / USD) tidak berpengaruh signifikan terhadap inflasi sementara suku bunga (SBI) juga tidak berpengaruh signifikan terhadap inflasi.
\end{abstract}

Kata kunci: Uang Beredar, Suku Bunga, Nilai Tukar (IDR / USD), Inflasi

\section{PENDAHULUAN}

Salah satu peristiwa moneter yang penting dan hampir dijumpai semua Negara di dunia adalah inflasi. Inflasi berasal dari bahasa latin "inflance" yang berarti meningkatkan. Secara umum inflasi adalah perkembangan dalam perekonomian, dimana harga dan gaji meningkat, permintaan tenaga kerja melebihi penawaran dan jumlah uang yang beredar sangat meningkat.Inflasi selalu ditandai dengan peningkatan harga-harga secara cepat. Inflasi merupakan proses kenaikan harga barang-barang secara umum dan berlaku terus-menerus. Ini tidak berarti bahwa harga berbagai macam barang itu naik dengan persentase yang sama. Mungkin dapat terjadi kenaikan harga umum barang secara terus-menerus selama periode tertentu, kenaikan yang terjadi hanya sekali saja (meskipun dalam persentase yang cukup besar) bukan merupakan inflasi (Nopirin, 1992 : 25).

Pada masa krisis terutama tahun 1998, Indonesia mengalami inflasi tertinggi yaitu mencapai $77,6 \%$. Peningkatan laju inflasi terutama disebabkan oleh depresiasi nilai tukar rupiah, krisis ekonomi dan ekspektasi terhadap inflasi yang tinggi.Sebelumnya Indonesia pernah mengalami hiper inflasi pada masa akhir orde lama yaitu pada tahun 
1966. Sehingga secara psikologis inflasi merupakan krisis bagi masyarakat Indonesia (A.M. Soesilo, 2002:1).

Secara umum inflasi menyebabkan timbulnya sejumlah biaya sosial yang harus ditanggung oleh masyarakat.Pertama, inflasi menimbulkan dampak negatif pada distribusi pendapatan. Masyarakat golongan bawah dan berpendapatan tetap akan menanggung beban inflasi dengan turunnya daya beli mereka. Sebaliknya, masyarakat menengah dan atas yang memiliki aset-aset finansial seperti tabungan dan deposito dapat melindungi kekayaannya dari inflasi, sehingga daya beli mereka relatif tetap.Kedua, inflasi yang tinggi berdampak negatif terhadap pertumbuhan ekonomi.

Salah satu kebijakan dalam pengendalian inflasi adalah kebijakan moneter. Untuk kebijakan moneter, pada umumnya kebijakan yang dilakukan oleh pihak otoritas moneter untuk mempengaruhi variabel moneter,jumlah uang beredar, suku bunga SBI dan nilai tukar.Pada umumnya kebijakan moneter adalah dicapainya keseimbangan intern (internalbalance) dan keseimbangan ekstern (external balance). Keseimbangan internal biasanya ditunjukkan dengan terciptanya keseimbangan kerja yang tinggi, tercapainya laju pertumbuhan ekonomi yang tinggi dan dipertahankan laju inflasi yang rendah. Disisi lain keseimbangan internal biasanya ditunjukkan dengan neraca pembayaran yang seimbang (Insukindro, 1994:204).

Kebijakanmoneter yang harus dilakukan di negara berkembang pada umumnya lebih berat dan sulit jika dibandingkan dengan negara-negara maju.Faktor pertama yang menjadi penyebabnya bahwa tugas untuk menciptakan penawaran uang yang cukup sehingga pertambahannya dapat selalu selaras dengan jalannya pembangunan yang memerlukan disiplin yang kuat di kalangan otoritas moneter dan pemerintah.

Kekurangan modal dan terbatasnya pendapatan pemerintah seringkali menimbulkan dorongan yang kuat kepada pemerintah untuk meminjam secara berlebihan kepada Bank Sentral. Kalau ini dilakukan, maka laju pertambahan jumlah uang beredar akan menjadi lebih cepat, akibatnya terjadi inflasi.

Faktor yang kedua yaitu, Bank Sentral di negara-negara berkembang harus secara lebih teliti dan berhati-hati mengawasi perkembangan penerimaan valuta asing dan mengawasi kegiatan dalam ekspor dan impor.Kegiatan di sektor ini sangat mudah menimbulkan inflasi karena berfluktuasinya harga-harga bahan mentah yang diekspor, sehingga penerimaan dari kegiatan ekspor mengalami perubahan yang tidak teratur, 
adakalanya kenaikannya besar sekali dan adakalanya menjadi sangat merosot. Akibatnya dari naik turunnya pendapatan ekspor, akan berpengaruhnya atas terjadinya ketidak stabilan ekonomi dan moneter serta ketidakstabilan pembangunan nasional.

Jika suatu negara ingin mempertahankan laju inflasi yang rendah, tentunya pemerintah tersebut harus menekan kenaikan harga. Usaha untuk menekan harga ini dapat dilakukan dengan menekan laju kenaikan jumlah uang beredar misalnya dengan pembatasan pemberian kredit atau dengan menaikkan suku bunga pinjaman (tight money policy).Tetapi dampak yang ditimbulkan adalah akan terjadi kelesuan investasi, dan meningkatnya pengangguran yang pada akhirnya akan menurunkan Pendapatan Nasional. Dengan fluktuasi tingkat suku bunga yang terjadi akan mempunyai implikasi yang penting terhadap sektor riil maupun sektor moneter dalam perekonomian.

Tingkat bunga yang tinggi akan menjadi masalah yang menyulitkan bagi investasi di sektor riil. Tapi tingkat bunga yang tinggi akan merangsang lebih banyak tabungan masyarakat. Untuk itulah tingkat fluktuasi bunga harus senantiasa terkontrol agar tetap mendorong kegiatan investasi dan produksi serta tidak mengurangi hasrat masyarakat untuk menabung dan tidak mengakibatkan pelarian modal ke luar negeri.

Faktor inflasi di Indonesia juga disebabkan oleh faktor luar negeri mengingat bahwa Indonesia adalah suatu negara dengan perekonomian terbuka yang di tengah-tengah perekonomian dunia. Dengan keadaan seperti itu maka implikasinya adalah adanya gejolak perekonomian di luar negeri akan berpengaruh terhadap perekonomian di dalam negeri. Bagi Indonesia dalam upaya membangun kembali perekonomiannya tingkat inflasi yang tinggi harus dihindari agar supaya momentum pembangunan yang sehat dan semangat dalam dunia usaha agar dapat tetap terpelihara.

\section{TINJAUAN PUSTAKA}

\section{Inflasi}

Inflasi adalah kenaikan harga secara umum, atau Inflasi dapat juga dikatakan sebagai penurunan daya beli uang.Makin tinggi kenaikan harga makin turun nilai uang.Defenisi di atas memberikan makna bahwa, kenaikan harga barang tertentu atau kenaikan harga karena panen yang gagal misalnya, tidak termasuk Inflasi. Ukuran Inflasi yang paling banyak adalah digunakan adalah: Consumer price indeks" atau " cost of living indeks". Indeks ini berdasarkan pada harga dari satu paket barang yang dipilih dan mewakili pola pengeluaran konsumen. (Kuncoro, 1998:46) 
adalah: kecenderungan dari harga untuk meningkat secara umum dan terus menerus. Kenaikan harga dari satu atau dua barang tidak dapat disebut Inflasi, kecuali bila kenaikan tersebut meluas atau mengakibatkan kenaikan kepada barang lainnya.Menurut Boediono (1994:155) definisi singkat dari Inflasi adalah kecenderungan dari harga-harga untuk menaik secara umum dan terus menerus.Kenaikan harga dari satu atau dua barang saja tidak disebut Inflasi.Syarat adanya kecenderungan menaik yang terus menerus juga perlu digaris-bawahi.Kenaikan harga-harga karena, misalnya, musiman, menjelang hari raya, bencana, dan sebagainya, yang sifatnya hanya sementara tidak disebut Inflasi.A.W. Phillips dari London School of Economics berhasil menemukan hubungan yang erat antara tingkat pengangguran dan tingkat perubahan upah nominal (Samuelson dan Nordhaus, 1997:327).Penemuan tersebut diperoleh dari hasil pengolahan data empirik perekonomian Inggris periode 1861-1957 dan kemudian menghasilkan teori yang dikenal dengan Kurva Phillips.

\section{Jumlah Uang Beredar}

Uang adalah segala sesuatu yang dapat dipakai/diterima untuk melakukan pembayaran baik barang, jasa maupun utang (Nopirin, 2007:2). Fungsi uang secara umum adalah sebagai berikut:

a. Sebagai satuan pengukur nilai, dengan fungsi ini maka nilai suatu barang dapat diukur dan diperbandingkan.

Misalnya mengukur nilai sebuah HP dengan menggunakan nilai rupiah, maka dapat diketahui perbandingan nilai antara HP dengan TV.

b. Sebagai alat tukar menukar, dengan adanya uang kita dapat membeli/menukarkan dengan barang lain sehingga mempermudah transaksi jual beli.

c. Sebagai alat penimbun kekayaan, dengan uang seseorang dapat menyimpan/menimbun kekayaan.

\section{Suku Bunga}

Suku bunga adalah jumlah bunga yang dibayarkan per unit waktu. Dengan kata lain, masyarakat harus membayar peluang untuk meminjam uang. Biaya untuk meminjam uang di ukur dalam Rupiah atau Dollar per tahun untuk setiap Rupiah atau Dollar yang dipinjam adalah Suku Bunga.

Menurut Boediono (1996:76), Suku Bunga adalah harga yang harus di bayar apabila terjadi pertukaran antara satu Rupiah sekarang dan satu Rupiah nanti. Adanya kenaikan suku bunga yang tidak wajar akan menyulitkan dunia usaha untuk membayar beban bunga dan kewajiban, 
karena suku bunga yang tinggi akan menambah beban bagi perusahaan sehingga secara langsung akan mengurangi profit perusahaan.

(Kasmir, 2008:131), bunga bank adalah sebagai balas jasa yang diberikan oleh bank yang berdasarkan prinsip konvensional kepada nasabah yang membeli atau menjual produkanya. Bunga juga dapat diartikan harga yang harus dibayar kepada nasabah (yang memiliki simpanan) dengan yang harus dibayar oleh nasabah kepada bank (nasabah yang memperoleh pinjaman).

\section{Nilai Tukar Rupiah}

Menurut Musdholifah \& Tony (2007), nilai tukar atau kurs adalah perbandingan antara harga mata uang suatu negara dengan mata uang negara lain. Misal kurs rupiah terhadap dollar Amerika menunjukkan berapa rupiah yang diperlukan untuk ditukarkan dengan satu dollar Amerika.

Menurut Triyono (2008), kurs (exchange rate) adalah pertukaran antara dua mata uang yang berbeda, yaitu merupakan perbandingan nilai atau harga antara kedua mata uang tersebut.

Jadi, Nilai Tukar Rupiah adalah suatu perbandingan antara nilai mata uang suatu negara dengan negara lain. Heru (2008) menyatakan bahwa nilai tukar mencerminkan keseimbangan permintaan dan penawaran terhadap mata uang dalam negeri maupun mata uang asing \$US.Merosotnya nilai tukar rupiah merefleksikan menurunnya permintaan masyarakat terhadap mata uang rupiah karena menurunnya peran perekonomian nasional atau karena meningkatnya permintaan mata uang asing \$US sebagai alat pembayaran internasional.Semkin menguat kurs rupiah sampai batas tertentu berarti menggambarkan kinerja di pasar uang semakin menunjukkan perbaikan.Sebagai dampak meningkatnya laju inflasi maka nilai tukar domestic semakin melemah terhadap mata uang asing.Hal ini mengakibatkan menurunnya kinerja suatu perusahaan dan investasi di pasar modal menjadi berkurang.

Heru (2008) menyatakan bahwa nilai tukar rupiah terhadap mata uang asing pun mempunyai pengaruh negatif terhadap ekonomi dan pasar modal. Dengan menurunnya nilai tukar rupiah terhadap mata uang asing akan mengakibatkan meningkatnya biaya impor bahan-bahan baku yang akan digunakan untuk produksi dan juga meningkatkan suku bunga. Walaupun menurunnya nilai tukar juga dapat mendorong perusahaan untuk melakukan ekspor. 


\section{Kerangka Berpikir}

Adapun kerangka berpikirnya adalah sebagai berikut :

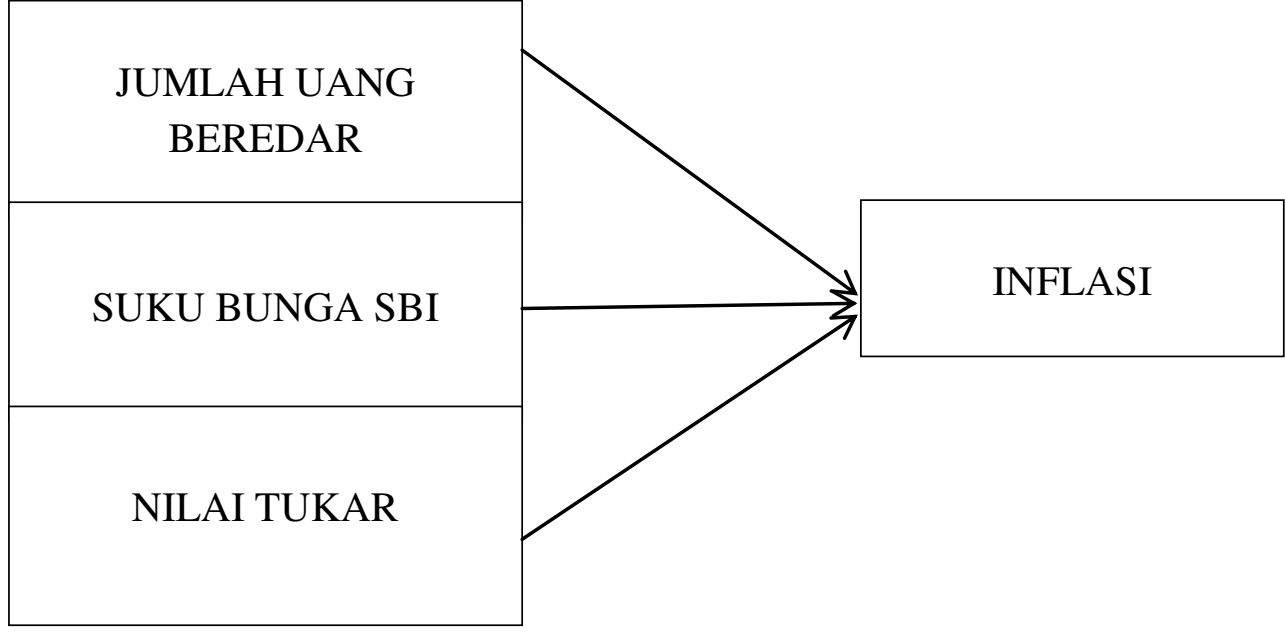

\section{Hipotesis}

Hipotesis adalah jawaban sementara atas masalah yang telah dirumuskan. Dari penjelasan teori dan perumusan masalah diatas, maka Hipotesis dirumuskan sebagai berikut :

Ha: Jumlah Uang Beredar, Suku Bunga SBI dan Nilai Tukar mempengaruhi Inflasi di Indonesia

\section{METODE PENELITIAN}

\section{Populasi dan Sampel}

Populasi dalam penelitian ini adalah Inflasi, Jumlah Uang Beredar, Suku Bunga SBI, dan Inflasi di Indonesia.Sampel adalah sebahagian atau wakil dari populasi yang menjadi objek penelitian.Sampel dalam penelitian adalah data Inflasi, Jumlah Uang Beredar, Suku Bunga SBI dan Nilai Tukar dari periode tahun 2004 sampai 2013.

\section{Operasionalisasi Variabel}

a. Inflasi adalah kenaikan harga secara umum, atau Inflasi dapat juga dikatakan sebagai penurunan daya beli uang

b. Jumlah Uang beredar adalah uang kertas dan uang logam ditambah simpanan dalam bentuk rekening Koran.

c. Suku Bunga adalah harga yang harus di bayar apabila terjadi pertukaran antara satu Rupiah sekarang dan satu Rupiah nanti 
d. Nilai tukar atau kurs adalah perbandingan antara harga mata uang suatu negara dengan mata uang negara lain

\section{Teknik Analisis Data}

Teknik analisis data yang digunakan dalam penelitian ini adalah menggunakan Model Regresi Linear Berganda (Multiple Regression Analysis Model). Analisis regresi linear berganda bertujuan untuk menguji hipotesis tentang kekuatan variabel independen terhadap variabel dependen dengan Model sebagai berikut :

$Y=\alpha+\beta 1 X 1+\beta 2 X 2+\beta 3 X 3+\mu$

Dimana :

$\begin{array}{ll}\mathrm{Y} & \text { : Inflasi (dalam persen) } \\ \alpha & \text { : Intercept } \\ \beta 1 \beta 2 \beta 3 & \text { : Koefisien regresi } \\ \mathrm{X} 1 & \text { : Jumlah Uang Beredar (dalam jutaan rupiah) } \\ \mathrm{X} 2 & \text { : Suku Bunga SBI (dalam persen) } \\ \mathrm{X} 3 & \text { : Nilai Tukar (dalam rupiah) } \\ \mu & \text { : Term of Error }\end{array}$

\section{HASIL PENELITIAN DAN PEMBAHASAN}

\section{a. Regresi linear Jumlah Uang Beredar, Suku Bunga SBI dan Nilai Tukar terhadap Inflasi Di Indonesia}

Untuk mendapatkan hasil regresi antara variabel independent (jumlah uang beredar, suku bunga SBI dan nilai tukar) dan variabel dependen (inflasi) maka digunakan data sekunder yang berasal dari BPS yang dicatat mulai dari tahun 2005-2014 dan diolah dengan menggunakan bantuan program komputer.Berikut ini hasil pengolahan data dengan menggunakan metode OLS (Ordinary Least Square).

Tabel 1

Coefficients $^{\mathrm{a}}$

\section{Hasil Regresi}

\begin{tabular}{|c|c|c|c|c|c|}
\hline \multirow[b]{2}{*}{ Model } & \multicolumn{2}{|c|}{ Unstandardized Coefficients } & \multirow{2}{*}{$\begin{array}{c}\text { Standardized } \\
\text { Coefficients } \\
\text { Beta }\end{array}$} & \multirow[b]{2}{*}{$\mathrm{t}$} & \multirow[b]{2}{*}{ Sig. } \\
\hline & $\mathrm{B}$ & Std. Error & & & \\
\hline $1 \quad$ (Constant) & -44.428 & 47.668 & & -.932 & .387 \\
\hline $\mathrm{X} 1$ & 2.452 & 2.905 & -.303 & -.844 & .431 \\
\hline $\mathrm{X} 2$ & .657 & .324 & .725 & 2.026 & .089 \\
\hline $\mathrm{X} 3$ & 15.495 & 11.420 & .392 & 1.357 & .224 \\
\hline
\end{tabular}

a. Dependent Variable: Y 
Dari hasil regresi diatas, dapat dibentuk model hasil estimasi sebagai berikut :

$Y=-44,428+2,452 X 1+0,657 X 2+15,495 X 3$

\section{Interpretasi Model}

Berdasarkan model estimasi diatas dapat dijelaskan pengaruh variabel independent yaitu nilai jumlah uang beredar (X1), suku bunga SBI (X2), dan jumlah uang beredar (X3) terhadap inflasi Indonesia sebagai berikut :

\section{Jumlah Uang Beredar}

Jumlah Uang Beredar ternyata berpengaruh positif terhadap inflasi di Indonesia.Hal ini ditunjukkan oleh koefisien regresi X1, yaitu sebesar 2,452 . Artinya, setiap kenaikan $1 \%$ jumlah uang beredar, maka tingkat inflasi akan naik sebesar 2,452\% (ceteris paribus).

\section{Suku Bunga SBI}

Suku Bunga SBI ternyata berpengaruh positif terhadap tingkat inflasi Indonesia.Hal ini ditunjukkan dengan nilai koefisien regresi $\mathrm{X} 2$, yaitu sebesar 0,657 . Artinya, setiap kenaikan $1 \%$ suku bunga SBImaka tingkat inflasi akan naik sebesar 0,657 \% (ceteris paribus).

\section{Nilai Tukar}

Nilai Tukar ternyata berpengaruh positif terhadap Inflasi Indonesia.Hal ini ditunjukkan dengan nilai koefisien regresi X3 yaitu sebesar 15,495. Artinya, setiap kenaikan $1 \%$ jumlah nilai tukar maka tingkat inflasi akan naik $15,495 \%$ (ceteris paribus).

\section{Pengujian Koefisien Regresi Secara Individual (Uji t Statistik) 1. Jumlah Uang Beredar}

Untuk variabel jumlah uang beredar diperoleh nilai t-hitung sebesar 0,844 dengan nilai probabilitas (signifikansi) sebesar 0,431. Dengan demikian Ho diterima, karena nilai probabilitas lebih besar dari nilai $\alpha$ $0,05(0,976>0,05)$ dan t-hitung > t-tabel $(-0,844>-2,447)$. Berarti dapat disimpulkan bahwa variabel jumlah uang beredar tidak berpengaruh nyata (signifikan) terhadap variabel inflasi Indonesia dengan pengujian pada tingkat kepercayaan $95 \%(\alpha=5 \%)$. 


\section{Suku Bunga SBI}

Untuk variabel suku bunga SBI diperoleh nilai t-hitung sebesar 2,026 dengan nilai probabilitas (signifikansi) sebesar 0,089. Dengan demikian Ho diterima, karena nilai probabilitas lebih besar dari nilai $\alpha 0,05(0,089>$ $0,05)$ dan t-hitung < t-tabel $(2,026<2,447)$. Berarti dapat disimpulkan bahwa variabel suku bunga SBI tidak berpengaruh nyata (signifikan) terhadap variabel inflasi Indonesia dengan pengujian pada tingkat kepercayaan $95 \%(\alpha=5 \%)$.

\section{Nilai Tukar}

Untuk variabel nilai tukar diperoleh nilai t-hitung sebesar 1,357 dengan nilai probabilitas (signifikansi) sebesar 0,224. Dengan demikian Ho diterima, karena nilai probabilitas lebih besar dari nilai $\alpha 0,05(0,224>$ $0,05)$ dan t-hitung < t-tabel $(1,357<2,447)$. Berarti dapat disimpulkan bahwa variabel nilai tukar tidak berpengaruh nyata (signifikan) terhadap variabel inflasi Indonesia dengan pengujian pada tingkat kepercayaan $95 \%$ $(\alpha=5 \%)$.

\section{Pengujian Koefisien Regresi Secara Bersamaan (Uji F Statistik)}

Untuk membuktikan nilai R-square tersebut diatas maka dilakukan pengujian dengan menggunakan uji $\mathrm{F}$.

Hipotesisnya adalah sebagai berikut :

$\mathrm{H}_{0}: \beta 1=\beta 2=0$

Ha: $\beta 1 \neq \beta 2 \neq 0$

Artinya, berdasarkan data yang tersedia, akan dilakukan pengujian terhadap $\beta 1$ dan $\beta 2$ secara bersama-sama, apakah sama dengan nol, yang berarti tidak berpengaruh signifikan terhadap variabel terikat, atau tidak sama dengan nol, yang berarti mempunyai pengaruh signifikan terhadap variabel terikat.

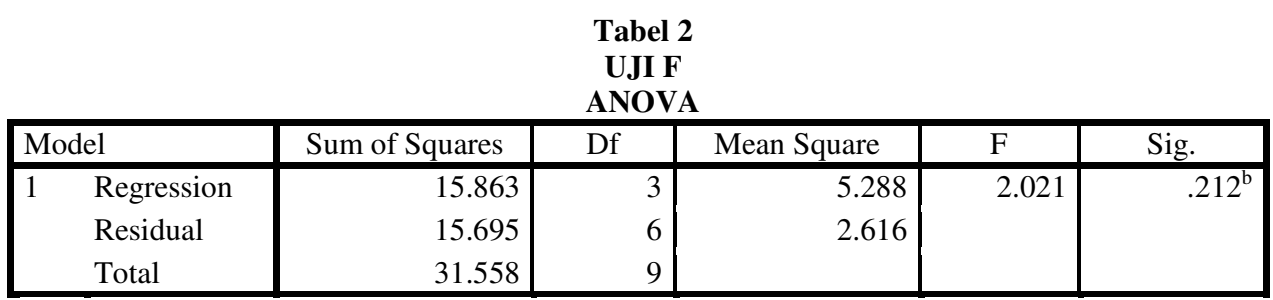

a. Dependent Variable: $\mathrm{Y}$

b. Predictors: (Constant), X3, X2, X1 
Berdasarkan hasil output program spss, diperoleh nilai F-hitung sebesar 2,021 dengan nilai probabilitas (signifikansi) adalah sebesar 0,212. Dengan demikian Ho diterima, karena nilai F-hitung < F-tabel $(2,021<$ 4,757) dan nilai probabilitas (signifikansi) lebih besar dari nilai $\alpha 0,05$ $(0,212>0,05)$. Berarti dapat disimpulkan bahwa variabel X1 (jumlah uang beredar), variabel X2 (suku bunga SBI), variabel X3 (nilai tukar) tidak berpengaruh secara nyata (signifikan) terhadap inflasi Indonesia (Y) pada tingkat kepercayaan $95 \%(\alpha=5 \%)$.

\section{Koefisien Determinasi $\left(\mathbf{R}^{2}\right)$}

Tabel 3

KOEFISIEN DETERMINASI

Model Summary ${ }^{\mathrm{b}}$

\begin{tabular}{|l|r|r|r|c|}
\hline Model & R & R Square & \multicolumn{1}{c|}{$\begin{array}{c}\text { Adjusted R } \\
\text { Square }\end{array}$} & $\begin{array}{c}\text { Std. Error of the } \\
\text { Estimate }\end{array}$ \\
\hline 1 & $.709^{\mathrm{a}}$ & .503 & .254 & 1.61736 \\
\hline
\end{tabular}

a. Predictors: (Constant), X3, X2, X1

b. Dependent Variable: Y

Berdasarkan hasil output program spss, dapat dilihat nilai $\mathrm{R}$-square adalah sebesar 0,503 yang berarti bahwa variabel X1 (jumlah uang beredar), X2 (suku bunga SBI), X3 (nilai tukar) secara bersama-sama mampu memberikan penjelasan variasi inflasi 50,3\% sedangkan sisanya $49,7 \%$ dijelaskan oleh variabel baru yang tidak disertakan dalam estimasi model.

\section{KESIMPULAN DAN SARAN}

\section{Kesimpulan}

Berdasarkan hasil penelitian mengenai pengaruh jumlah uang beredar, suku bunga SBI dan nilai tukar terhadap inflasi di Indonesia, maka dapat diambil kesimpulan sebagai berikut :

1. Dari hasil uji F, disimpulkan bahwa jumlah uang beredar, suku bunga SBI dan nilai tukar selama periode 2005 sampai dengan 2014 tidak berpengaruh signifikan secara simultan terhadap inflasi di Indonesia pada tingkat signifikansi 5\%. Dengan demikian hipotesis penelitian ditolak. 
2. Berdasarkan uji parsial (uji t), variabel jumlah uang beredar, suku bunga SBI dan nilai tukar tidak berpengaruh nyata terhadap variabel inflasi di Indonesia dengan pengujian pada tingkat kepercayaan $95 \%$ ( $\alpha=5 \%$ ).

3. Nilai koefisien determinasi (R) sebesar 0,503 yang berarti bahwa variabel X1 (jumlah uang beredar), X2 (suku bunga SBI), X3 (nilai tukar) secara bersama-sama mampu memberikan penjelasan variasi inflasi $50.3 \%$ sedangkan sisanya 49,7\% dijelaskan oleh variabel baru yang tidak disertakan dalam estimasi model.

\section{Saran}

Dengan melihat kesimpulan dan hasil pembahasan diatas, maka penulis akan mencoba mengemukakan beberapa saran. Adapun saran yang penulis kemukakan adalah :

1. Suku bunga memiliki pengaruh signifikan terhadap inflasi, oleh karena itu kebijakan moneter harus dapat berupaya menjaga tingkat suku bunga untuk kestabilan inflasi.

2. Bagi akademisi yang bermaksud melakukan penelitian lebih lanjut, hendaknya dapat menambah variabel bebas lain yang relevan dengan inflasi, sehingga didapat informasi yang lebih akurat untuk menekan laju inflasi.

\section{DAFTAR PUSTAKA}

Boediono.1994. Ekonomi Makro.Seri Sinopsis Pengantar Ilmu Ekonomi No. 2, Edisi ke-4, BPFE: Yogyakarta.

Insukindro, 1994.Komponen Koefisien Regresi Model Ekonomi: Sebuah Study Kasus Impor Barang di Indonesia. Jurnal Ekonomi dan Bisnis Indonesia, Vol 5 , No 204

Kasmir.2008. Bank Dan Lembaga Keuangan Lainnya. Edisi Revisi 8. Jakarta: PT Raja Grafindo Persada.

Mishkin, Frederic S. 2008. Ekonomi Uang, Perbankan, dan Pasar Keuangan: Buku 2. Terjemahan Lana Soelistianingsih dan Beta Yulianita G. Jakarta: Salemba Empat.

Mudrajad Kuncoro.1998. Metode Kuantitatif Teori \& Aplikasi Untuk Bisnis \& Ekonomi. Yogyakarta: YKPN.

Nopirin. 2007. Ekonomi Moneter. Yogyakarta: BPFE 
Putong, Iskandar.2002. Ekonomi Mikro dan Makro, Edisi Kedua.Jakarta: Penerbit Ghalia Indonesia.

Samuelson. Paul. A. \& Nordhaus. William D. 1997. Makro Ekonomi, Jakarta: Erlangga.

Simorangkir, Iskandar dan Suseno. 2004. Sistem dan Kebijakan Nilai Tukar, Seri Kebanksentralan No.12. Pusat Pendidikan dan Studi Kebanksentralan Bank Indonesia (PPSK BI) : Jakarta.

Tandelilin, Eduardus. 2001. Analisis Investasi dan Manajemen Portofolio. Edisi Pertama. Yogyakarta.BPFE.

Weston, J. Fred dan Brigham, Eugene F. 1990.Dasar-Dasar Manajemen Keuangan.Jilid I. Edisi Kesembilan. Jakarta. Erlangga. 